\title{
Women Entrepreneurial Networks and Small Business Development: A Study Based on Tourism Industry in Sri Lanka: Ongoing Research Project
}

Surangi H. A. K. N. S.

Business School, Faculty of Business and Law, University of Lincoln, United Kingdom shapugoda@lincoln.ac.uk

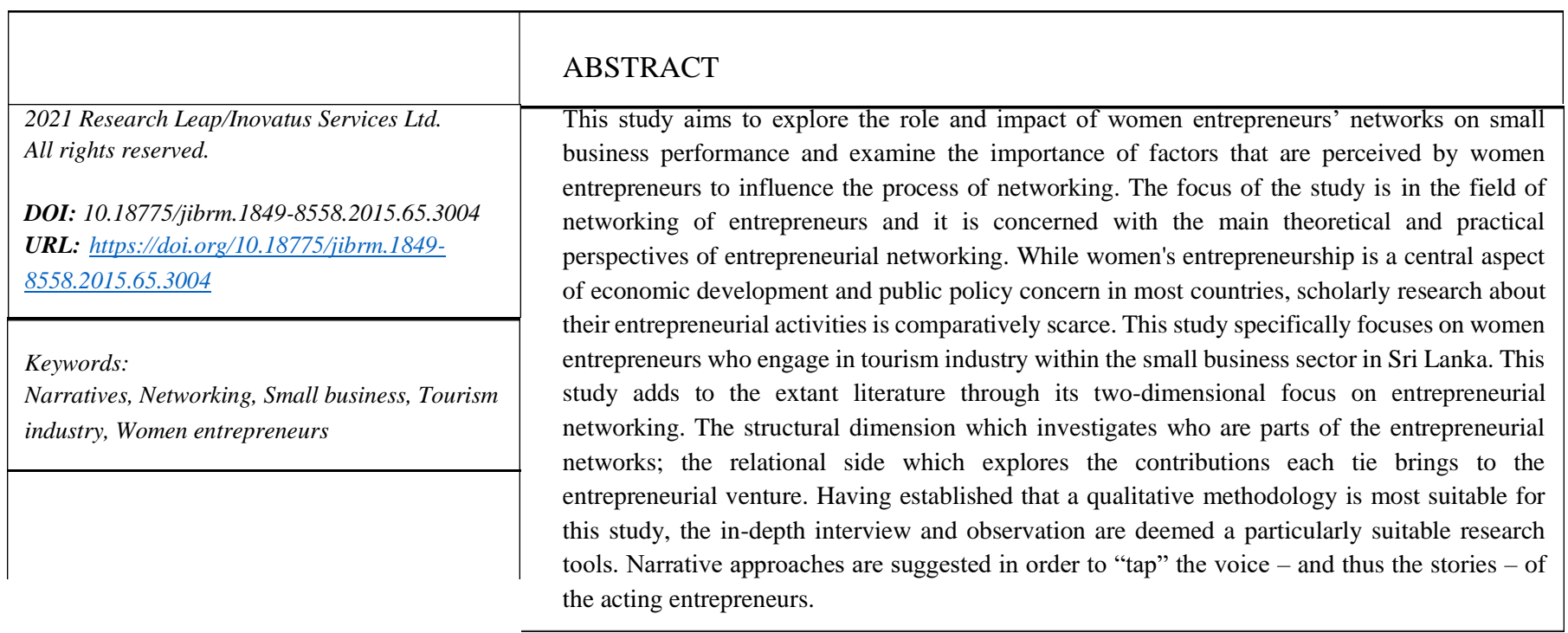

\section{Introduction}

Networking is an influential tool by which entrepreneurs use a wide variety of contacts to help them achieve their business and professional objectives and it gives them greater access to information, resources, new clients and people with similar business interests so on (Ascigil and Magner, 2009; Barnir and Smith, 2002). Networking is mostly important for women, who generally have more limited access to information and business contacts, whether through various membership such as trade organisations, business networks and business clubs. Traditional role patterns continue and the combination of running a business and managing the home leaves little time for other activities (Loscocco et al., 2009; Mand, 2006; Maclean, 2010). Unlike most male counterparts, many women entrepreneurs combine setting up and running a business with managing the household (Maclean, 2010).

The rise of female entrepreneurs has involved academic interest and female entrepreneurship has developed as a separate research field (Tulus, 2009). Academic interest in female entrepreneurship is inspired by both the economic and equality implications of the occurrence. Given the fact that entrepreneurship is considered as the main source of economic growth, employment, poverty alleviation, regional development and innovation, women are a readily available resource that countries at different stages of economic development may use to accomplish economic progress (UNDP, 2011). Indeed, Tulus (2009) revealed positive relationship between the female share in entrepreneurship and economic performance at both country and regional levels.

Entrepreneurial networks, as an important strategy for the development of small business sector, are increasingly the focus of attention for entrepreneurs, public authorities, policy makers and academics (Sherre and Keith, 1997; Audrey and David, 2006; Premarathna, 2001). For example, a number of researches (Premarathna, 2008; Daniel 2010; Yee 2011) have studied the importance of networking in entrepreneurial success. Networking linkages can be seen to be important for small firms. The need for external assistance to strengthen an often weak base of resources is even more crucial in the case of the small business sector in many countries. Therefore; it is difficult for many small organizations to survive without any support from the network actors.

Over the past few years much has been written about the rapid spread of various types of firm networking, the area of women entrepreneurs' networks and small business entrepreneurship is still a challenging research field. This study is devoted to 
explore the role and impact of women entrepreneurs on small business development and effect factors that are perceived by women entrepreneurs for their networking relationship.

Networks can be defined as personal relationships between an entrepreneur and his 'external actors' (Robinson, 2007; Birley, Cromie and Myers, 1991). The external actors (outsiders) can be individuals or organizations. Entrepreneurs build up such network relationships (contacts) in order to obtain necessary resources and to perform activities

\section{Background to the Study}

Small business enterprises play a vital role in the economies of both developed and developing countries, representing well over $60 \%$ of all manufacturing enterprises in the world (Michael and Markarues, 2009; Kodithuwakku, 2008). This sector constitutes $95 \%, 97.3 \%$ and $85.5 \%$ of all businesses in United Kingdom, New Zealand and Australia respectively (Kodicara, 2008). The small and micro enterprises play a major role in the Kenyan economy and according to the Kenya National Bureau of Statistics 2007, the sector contributed over 50 percent of new jobs created in the year 2005 (Michael, Makarius and Samuel, 2009). About $98 \%$ of enterprises in most Asian countries are classified as small enterprises and they make contribution heavily to total employment in any nation frequently representing more than $50 \%$ of total employed (Geoffrey, 2009). Small and medium enterprises in Pakistan in 2005 contributed over $30 \%$ to GDP (Muhammad, 2007).

The role of the Small business sector has become very significant and they have been identified as an important strategic sector for promoting growth \& social development of Sri Lanka. Over the years, this sector has gained wide recognition as a major source of employment, income generation, poverty alleviation and regional development (White Paper: Task Force, 2009). Small business Enterprises play an important role in job creation; this is evident from table 1 which captures the employment generated by micro $(<10$ persons) and small and medium enterprises (10-99 persons) as published by the Department of Census and Statistics (DCS).

Table 1: Number of persons engaged in micro, small and medium enterprises, 1992-2005 (DCS Annual Survey of Industries 2003, DCS data 2007)

\begin{tabular}{|c|c|c|c|c|c|c|c|c|c|c|}
\hline Size & \multicolumn{10}{|c|}{ Persons engaged } \\
\hline \multirow{2}{*}{$\begin{array}{l}\text { No of } \\
\text { Persons }\end{array}$} & \multicolumn{2}{|l|}{1992} & \multicolumn{2}{|l|}{1993} & \multicolumn{2}{|l|}{1996} & \multicolumn{2}{|l|}{1997} & \multicolumn{2}{|l|}{2005} \\
\hline & No: & $\%$ & No: & $\%$ & No: & $\%$ & No: & $\%$ & No: & $\%$ \\
\hline$<10$ & 2,911 & 1 & 3,002 & 1 & 46,995 & 9 & 48,225 & 10 & 53,352 & 11 \\
\hline $10-99$ & 44,406 & $\begin{array}{l}1 \\
5\end{array}$ & 48,389 & 14 & $\begin{array}{l}119,14 \\
6\end{array}$ & $\begin{array}{l}2 \\
2 \\
\end{array}$ & $\begin{array}{l}113,40 \\
8\end{array}$ & 23 & $\begin{array}{l}190,63 \\
8\end{array}$ & 17 \\
\hline Total & $\begin{array}{l}292,73 \\
6\end{array}$ & & $\begin{array}{l}345,03 \\
6\end{array}$ & & $\begin{array}{l}536,91 \\
3\end{array}$ & & $\begin{array}{l}495,35 \\
5\end{array}$ & & $\begin{array}{l}181047 \\
5\end{array}$ & \\
\hline
\end{tabular}

From the inception of industrialization of the Sri Lankan economy, small business sector was recognized as an important sector to be developed. But the progress of this sector was not up to expectation and it had high failure rate and they are continuously facing various problems such as lack of finance and other resources, networking, marketing etc. (Premarathna, 2002; Rathnayake, 2006). Considering table 2 it can clearly be identified that number of small business establishments is very high but value added is very low when compared to the three other sectors. Therefore, the contribution of small business sector to the national economy in Sri Lanka is still low when compared with the other developed and developing countries. Nevertheless, according to recent available statistics from various sources, the small For instance, their capital-labor ratio is less than one-third of that of manufacturing as a whole. The productivity of the sector is considerably lower (Premaratna, 2001).

Table 2: Servicers classified by persons engaged, 2008 (DCS , 2009)

\begin{tabular}{|l|l|l|l|l|}
\hline $\begin{array}{l}\text { Size-No of } \\
\text { persons }\end{array}$ & No of establishment & No of persons & Out put & Value added \\
\hline$<10$ & 39.2 & 2.9 & 0.7 & 0.6 \\
\hline $10-39$ & 36.8 & 7.6 & 4.1 & 4.2 \\
\hline $40-99$ & 12.1 & 8.4 & 5.7 & 5.5 \\
\hline 100 above & 11.9 & 81.1 & 89.5 & 89.7 \\
\hline All & 100 & 100 & 100 & 100 \\
\hline
\end{tabular}

In this setting, many researchers have considered these problems and they have found out various constraints such as finance, lack of planning and networking (Premarathna, 2002, 2005; Rathnayake, 2006; Selvamalar, 2005). Nevertheless, the ideal solution is not yet up to expectation. Moreover, some researches into small-business development revealed that the rate of failure of small scale businesses in developing countries is higher than in the developed world (Marlow, 2009).

Tourism is an industry that depends on synergy, partnership and working together. Therefore, the network approach is highly relevant to the study of tourism industry. There should be strong linkages existing between tourism with the other external bodies to survive in the field. Outsourcing, subcontracting or other linkage arrangements between businesses in hospitality industry and other external actors are crucial means of developing small enterprises. For

tourism to be beneficial in terms of income generation, economic growth, employment generation, poverty alleviation, and rural development, it has to be linked to local economies such as agriculture and micro and small scale enterprises (Patience and George, 2009).

The economy of the Sri Lanka mainly depends on plantation crops, apparel industry, tourism and foreign employment. Tourism has been a dynamic income generation source for the Sri Lankan economy by now. Tourism continued its position as fourth largest foreign exchange earner even in the year 2009 and the portion of tourism's contribution to foreign exchange earnings in 2009 amounted to $2.6 \%$ (SLTDA, Annual Statistical Reports 2009). The political and economic stability has arrived after period of 30 years waging war and it can be clearly seen strong green light for the industry to grow at a very fast rate as never in the history before. Blessed with around seven world heritages named by UNESCO, Sri Lanka is considered to be one of the most important cultural and biodiversity hotspot areas of the world though it is a small country. This symbolizes that the island is having immense possibilities and potentials in converting the destination towards a center in attracting more and more tourists and it will result in attracting foreign exchange as well as nurturing new ventures related to the industry.

The Sri Lanka Tourism industry depends heavily on its Small Enterprises and many Establishments are sole proprietor or partnerships (SLTDA 2011).

Table 3: Composition of tourism business in 2011 (SLTDA 2011) 


\begin{tabular}{|l|l|l|l|l|l|}
\hline Business type & $\begin{array}{l}\text { Total } \\
\text { establishment }\end{array}$ & Small & & $\begin{array}{l}\text { Medium and } \\
\text { Large }\end{array}$ & \\
\hline $\begin{array}{l}\text { Hotels and boutiques } \\
(39)\end{array}$ & 287 & 202 & $70 \%$ & 85 & $30 \%$ \\
\hline Guest houses & 497 & 386 & $78 \%$ & 111 & $22 \%$ \\
\hline Restaurants & 357 & 279 & $78 \%$ & 78 & $22 \%$ \\
\hline Travel agents & 559 & 458 & $81 \%$ & 101 & $19 \%$ \\
\hline Homestay units & 71 & 41 & $100 \%$ & 0 & - \\
\hline Bungalows & 36 & 26 & $100 \%$ & 0 & - \\
\hline Shops & 140 & 107 & $76 \%$ & 33 & $24 \%$ \\
\hline
\end{tabular}

The figure (table 3 ) says that more than $75 \%$ of tourism businesses belong to the small category. According to the SLTDA, in 2011 there were close to 1907 tourism-related businesses throughout the country, with 57786 people employed in jobs directly related to tourism while indirect employment was 80899.

\subsection{Sri Lankan Women Entrepreneurs and their Network Relationship}

Considering the average rate of business start-up from 1998 to 2002 , it can be noted that the number of women entrepreneurs' rate $(0.8 \%)$ is low compare to their male counterpart $(2.5 \%)$ in Sri Lanka (UN, 2003). Moreover, typical woman entrepreneurs' business enterprises are very small, with low turnovers, a low number of employees and no professional assistance (UN, 2003). In the process of entrepreneurship, women have to face a greater ranging of problems associated with entrepreneurship, than men, and these problems can be doubled because of her dual role as a wage earner, and a homemaker (Selvamalar, 2005).Women in entrepreneurship have been largely neglected both in society in general and in the social sciences. Not only have women lower participation rate in entrepreneurship than men but they also generally choose to start and manage firms in different industries than men tend to do (Brush, 1992). Women entrepreneurs play a non-trivial role in the economy, they face challenges and obstacles different from those faced by men and they act differently (UN, 2003).

Sri Lankan women entrepreneurs have fewer business contacts and lack knowledge of how to deal with the supporting organizations. Moreover, most women entrepreneurs operate on a small scale, and are generally not members of professional organizations or part of other networks in Sri Lanka (UNESCAP, 2005; Tules, 2009). Most existing networks are male dominated and sometimes not particularly welcoming to women but prefer to be exclusive (Premaratna, 2002; Thirkawela, 2011). Even when a woman does venture into these networks, her task is often difficult because most network activities take place after regular working hours. Lack of networks also returns women's awareness and exposure to good role models. Few women are invited to join trade of missions or delegations, due to the combined invisibility of women-dominated sectors or subsectors and of women as individuals within any given sector. As an example of this, at a small and medium enterprises trade fair among south Asian countries held in Sri Lanka in 2004 where it has been estimated than women operate around half of all SMEs, less than 20 women were registered among the approximately 250 participants (UNESCAP, 2005). Information is a most important resource for women entrepreneurs. Because, information can relate to markets, suppliers, costs and technology, and networks have emerged as key strategy for giving support to women entrepreneurs. Networking is very important to the success of a business, and it is identified as one access to information, new customers and suppliers (UNESCAP, 2005; Mya, 2011).

In most of the Asian countries like Sri Lanka women are viewed as weak, passive, obedient or submissive. Furthermore, dominant religious beliefs and traditions do not favour women being involved in outside activities. In some cases society has some stereotype such as weakness in a man if his wife is working in business. When women are involved in business activities, they have to deal with many people, and sometimes travel away from their homes and participate in business parties like cocktail. Such things are not well accepted by Asian societies (Ranasingha, 2009; UNESCAP, 2005; Ram and Seela, 2010; Surangi, 2010;

Surangi, 2008).

Business enterprises have contacts with a number of groups. These parties can be social networking, commercial networking and profesional networking.According to the research findings women entrpreneurs prefer especially to keep social networking with friends and relatives compared to their male counterparts in Sri Lanka .In contrast, majority of male entrpreneurs prefer to have close connections with commercial networking (Surangi, 2010; Wasanthi, 2011).

Sri Lankan society is still patriarchal and Sri Lankan women are traditionally considered homemakers and not businesspersons. In a previous stating, the majority of woman mentioned that they received excellent or good family support for their business and they said that it is difficult for them to manage the entire business without the help from male counterparts (Surangi, 2010; Rathnayaka, 2006). Women's family obligations also bar them from becoming successful entrepreneurs in both developed and developing nations (Botha, 2006). Having primary responsibility for children, home and older dependent family members, few women can devote all their time and energies to their business. Moreover, business success depends on the support extended by family members (Surangi, 2010).

\section{Objectives of the Study}

Researchers have interpreted gender differences in network composition as posing a disadvantage for women in the business world and weak ties are the source of male entrepreneurs success (Foss, 2010; Kristina, 2010; Wendy and Doyle, 2001). Women who include greater proportions of kin and female in their discussion networks may secure greater social support than men, but at the cost of sacrificing the necessary instrumental support needed for economic achievement (Klyver, 2007, 2011). Social support provides the emotional strength owners and managers need to cope with daily exigencies, but such ties may also limit the diversity and reach of women's networks. Women's networks tend to be more limited and to focus on family and friends whereas male entrepreneurs have wider networks (Chirs et al., 2011). Taken that as given, this study attempts to achieve the following objectives.

1. To explore the role and influence of women entrepreneurs' networks on small business performance

2. To examine the importance of factors those are perceived by women entrepreneurs to influence the process of their networking. 


\section{Research Questions}

To achieve the research objectives, the study seeks the following research questions.

1. Why and how women entrepreneurs form their networks?

2. What is the contribution of each network actors to the development of small businesses?

3. What are the influencing factors for women entrepreneurs' process of networking?

\section{Research Methodology}

Given the limited understanding of the role of the women entrepreneurs' networks in the small business development, a qualitative research method will be considered the most appropriate, as it is useful in areas that are not well advanced theoretically. Therefore, this study is exploratory in nature and data are qualitative. Consequently, the research process of this study is inductive rather than deductive. Thus, this study adopts a phenomenological approach to obtain a deep understanding of entrepreneurs' experience of their networks, revealing the impact of these network relationships on the small business performance.

Having established that a qualitative methodology is most suitable for this study, the in-depth interview and observation are deemed a particularly suitable research tools. The in-depth interview enables the researcher to understand other persons' "constructions of reality", by allowing interviewees to respond in their own language .The interview type, which will be chosen for this research, can be referred to as semi- structured. Completely unstructured interviews are considered inappropriate due to the risk that the interviewer would fail to collect the desired information. On the other hand, the imposition of too rigid a structure on the interview might have inhibited the flow of information and might have prevented the emergence of useful and revealing insights.

The sampling frame of businesses in the hospitality sector in Sri Lanka will be obtained from list of divisional secretarial offices and tourist board. The lists included some basic information such as date of registration, type of business (hotel, guest house, restaurant, travel agencies, shops etc.) as well as their contact details. Purposive sampling method will be used to select entrepreneurs.

\section{Contribution to Knowledge}

The purpose of this research is to study the role of entrepreneurs' networks and its impacts on small- scale business performance that run by the women entrepreneurs in Sri Lanka and influencing factors for women entrepreneurs networking process. Entrepreneurial networking and small business development have been a well-researched area by scholars for many years especially in developed countries. But, there were few studies carried out to examine the relationship between entrepreneurial networking and business success in Sri Lanka. In the networking literature, women entrepreneurs are under researched area in both developed and developing countries and there is limited academic research with empirical material on this topic specifically focusing on women entrepreneurs in Sri Lanka. As an attempt to fill the gap this study will examine how entrepreneurial networking among women entrepreneurs impact on small business growth in Sri Lanka.

Much of the research on entrepreneurial networks is concerned with structural characteristics. The connectionist perspective studies are mainly concerned with the content flowing across network relationship (Sullivan, 2006). In the present work, researcher considers both structural and connectionist perspectives to be important. Apart from structural and connectionist perspectives, the research on entrepreneurship has emphasized influencing factors of the networking process for women entrepreneurs (Johannisson, 2000; Zhao, Frese and Giardini, 2005). Most social network studies focus only on the outcomes of networks (e.g., business growth) rather than on their influencing factors. In this study, the researcher will concentrate on the influencing factors for women entrepreneurs' networking process, in particular, on how women entrepreneurs actively enlarge social networks in order to achieve higher business growth. Fewer studies have explored the factors influencing the network process (Zhao, Frese and Giardini, 2005).

The objective of this research is to gain an understanding of the networking process in which women small firm ownermanagers engage. It has been noted that, while much research has been undertaken to discover the structure of small firm networks, less is known about the influencing factors for women entrepreneurs networking (Moghli and Muala, 2012). Such a situation has been explained by the fact that structural dimensions of a network are eager to quantitative methods, and accordingly, these have tended to dominate small firm research to date .However, it has been stated that the understanding of networks proffered by such quantitative methods is limited and in some cases, confusing and this research will adopt a qualitative methodology.

Moreover, this study is worth to academic research and policy development because of the significant contribution these businesses could make to economic development, employment generation of the country.

The finding of this research work is significant for several reasons. Most importantly, this research work will throw more light on the issue of networking of women entrepreneurs in the Sri Lankan economy. The result of this study will help consultants, researchers and policy makers on women entrepreneurship to understand the role of entrepreneurial networking and its impact on the small business development better so as to help women to make supported business decisions. The result of this study can help women entrepreneurs who are seeking information and resources on how to handle their business. It will create an opportunity for further research on motivation and women entrepreneurship, small business sector and tourism industry. 


\section{Conclusion}

In summary, despite the research attention on entrepreneurial networking in recent years, prior work has tended to focus on how actors connect (structural dimension), however, there is a lack of research about the resources actors can potentially gain access to by examining with whom they connect and what resource they have (relational dimension). Therefore, while the study of the structural dimension of networks has been found to disclose variations between male and female business owners, there is still a lack of research into the relational dimension of networks which may uncover differences in resource mobilization. Moreover, few studies have acknowledged the impact of gender on networking experiences (Garcia and Carter, 2009) .To date, researchers focus to study gender differences in entrepreneurial networking (Klyver, 2007; Batjargal et al., 2009; Miller, Besser and Riibe, 2007; D'Exelle and Holvoet, 2011; Foss, 2010; Garcia and Carter, 2009), but very little research has been conducted specifically focus on women (Sappleton, 2009; Roomi, 2009; Tsuchiya, 2010). In addition to, it can be clearly seen that quantitative research are dominant in networking literature. In all respect, this research is a preliminary step towards filling this academic gap. In addition to, the controversial evidence of women entrepreneurial networking identified by the academic literature and the shortcomings of the existing research in women entrepreneurs' networks provide compelling reasons for further research on women entrepreneurs' networks in entrepreneurship in a transition context.

\section{Bibliography}

1. Ascigil, S. F. and Magner, N. R. (2009). Business incubators: leveraging skill utilization through social capital. Journal of Small Business Strategy, 20(1), 1934.

2. Audrey, G., David, C. and Steve, R. (2006). Networking in SMEs: Evaluating its contribution. International Business Review, 15(3), 278-293 Crossref

3. Barnir, A. and Smith, K. A. (2002). Inter-firm alliances in the small business: The role of social networks. Journal of Small Business Management, 40(3), 219-232. Crossref

4. Batjargal, et al. (2009). Women and men entrepreneurs' social networks and new venture performance across cultures. In Academy of Management Annual Meeting Proceedings, Conference Proceeding. Crossref

5. Birley, S., Cromie, S. and Myers, A. (1991). Entrepreneurial Networks: Their Emergence in Ireland and Overseas. International Journal of Small Business, 9(4), 56-74.

6. Brush, C. G. (1992). Research on women business owners: past trends, a new perspective and future directions. Entrepreneurship Theory and Practice, 16(4), 5-30.

7. D'Exelle, B. and Holvoet, N. (2011). Gender and network formation in rural Nicaragua: a village case study. Feminist Economics, 17(2), 31-61.
8. Daneil, T. (2010). Network development and knowledge creation within the foreign market: A study of international entrepreneurial firms. Entrepreneurship \& Regional Development, 22(5), 379-402. Crossref

9. Department of Census and Statistics Sri Lanka reports 2008, 2009, 2010.

10. Foss, L. (2010). Research on entrepreneurial networks: The case for a constructionist feminist theory perspective. International Journal of Gender and Entrepreneurship, 2(1), 83-102. Crossref

11.

12. Garcia, M. C. D. and Carter, S. (2009). Resource mobilization through business owners' networks: is gender an issue?. International Journal of Gender and Entrepreneurship, 1(3), 226-252.

13. Johannisson, B. (2000). Networking and entrepreneurial growth: Hand book of entrepreneurship. London: Blackwell.

14. Klyver, K. and Grant, S. (2010). Gender differences in entrepreneurial networking and participation. International Journal of Gender and Entrepreneurship, 2(3), 213-227. Crossref

15. Klyver, K. (2011). Gender differences in entrepreneurial networks: adding an alter perspective. Gender in Management, 26(5), 332-350.

16. Klyver, K. and Siri, T. (2007). Entrepreneurial network composition: An analysis across venture development stage. Women in Management Review, 22(8), 682-688.

17. Klyver, K., Kevin, H. and Denny, M. (2007). Influence of social network structure on entrepreneurship participation: A study of 20 national cultures. International Entrepreneurship Management Journal, 4(3), 331-347. Crossref

18. Kodicara, A. G. (2008). Conceptualising a model to promote post start-up small business growth in Sri Lanka. Christchurch: University of Canterbury.

19. Kodithuwakku, H. (2006). Constraints of small business: based on the manufacturing sector in Sri Lanka. The Peradeniya Journal of Economics, 1(2).

20. Kristina, A. B. (2010). The paradox of gender equality: an entrepreneurial case study from Sweden. International Journal of Gender and Entrepreneurship, 2(1), 10-26.

21. Loscocco, K. et al. (2009). Enterprising Women: A Comparison of Women's and Men's Small Business Networks. Gender \& Society, 23(3), 388-411. Crossref

22. Maclean, K. (2010). Capitalizing on Women's Social Capital? Women-Targeted Microfinance in Bolivia. Development and Change, 41(3), 495-515.

23. Mand, K. (2006). Social relations beyond the family? Exploring elderly South Asian women's friendships in London, Community. Work and Family, 9(3), 309323.

24. Michael, B., Makarius, M. and Samuel, M. (2009). Management of business challenges among small and micro enterprises in Nairobi-Kenya. KCA Journal of Business Management, 2(1), 16-31. Crossref

25. Miller, N. J., Besser, T. L. and Riibe, J. V. (2007). Do strategic business networks benefit male- and female- 
owned small community business. Journal of Small Business Strategy, 17(2), 53.

26. Moghli, A. A. and Muala, A. A. (2012). Impact of entrepreneurial networks in the success of business on-going stage in jordanian manufacturing companies. American Academic \& Scholarly Research Journal, 4(2), 31-40.

27. Mya, T. A. P. (2011). The impact of ICT and networking on the business performance of one Tambon one product enterprises in greater Bangkok and metropolitan areas (Doctoral dissertation). Bangkok: [T. A. P. Mya].

28. Premarathna, S. (2001). Networks, resources and small business growth: the experience from Sri Lanka. Journal of Small Business Management, 39(4), 363-371. Crossref

29. Premarathna, S. (2008). Entrepreneurial Networks and SME Development: A Managerial Approach. The Peradeniya Journal of Economics, 2(1-2).

30. Ram, A. and Seela, A. (2010). 2020 Vision for Gender Sensitive Development and Environment: Commemorative Article for the International Women's Day 2010.

31. Ranasingha, S. B. (2009). Women Entrepreneurs of Sri Lanka: Contributory Factors to their Success. Sri Lankan Journal of Humanities and Social Sciences, 1(2).

32. Rathnayake, C. K. (2006). Issues and challenges of small business entrepreneurship: A case study of Kurunagala district. The Peradeniya Journal of Economics, 1(1-2).

33.

34. Robinson, S. (2007). Business failure rates: a look at sex and location. Academy of Entrepreneurship Journal, 13(1).

35. Roomi, M. A. (2009). Impact of social capital development and use in the growth process of womenowned firms. Journal of Enterprising Culture, 17(4), 473-495.

36. Sappleton, N. (2009). Women non-traditional entrepreneurs and social capital.

37. International Journal of Gender and Entrepreneurship, 1(3), 192-218

38. Selvamalar, A. (2005). An insight to the constraints faced by women entrepreneurs in Sri Lanka. Paper presented in International conference of women entrepreneurs, Malaysia.

39. Sherrie, E. H. and Keith, G. P. (1997). An Emergent Theory of Structure and Outcomes in small firm strategic manufacturing networks. The Academy of Management Journal, 40(2), 368-403. Crossref

40. SLTDA. Annual Statistical Reports 2008, 2009, 2010, 2011.

41. Sullivan, D. M. (2006). Dynamic entrepreneurial networks: an investigation of entrepreneurs, new ventures and their networks (Doctoral dissertation). Florida: [D. M. Sullivan].

42. Surangi, H. A. K. N. S. (2008). Equity and gender in university education in Sri Lanka. In International conference on Teaching \& Learning in Higher education, Kualalampur, Malaysia.

43. Surangi, H. A. K. N. S. (2010). Gender differences in constraints faced by Micro Entrepreneurs in Gampaha
District (M Phil thesis). Peradeniya: [S. H. A. K. N. S.].

44. Thrikawela, S. S. (2011). Impact of Strategic Networks for the Success of SMEs in Sri Lanka. World Journal of Social Sciences, 1.

45. Tsuchiya, R. (2010). Neighborhood social networks and female self-employment earnings in Taiwan. International Entrepreneurship Management Journal, 6, 143-161. Crossref

46. Tulus, T. (2009). Women entrepreneurship in Asian developing countries: Their development and main constraints. Journal of development and Agricultural Economics, 1(2), 27-40.

47. United Nations. (2003). Economic and social commission for Asia and pacific: putting gender mainstreaming into practice.

48. UNDP. (2011). Human Development Report.

49. UNESCAP. (2005). Economic and social commission for Asia and pacific: developing women entrepreneurs in south Asia: issues, initiatives and experiences. Bangkok.

50. Wasanthi, M. (2011). Does culture impact on social network of ethnic small business entrepreneurs. In ICSB 2011 World Conference.

51. White Paper: Task Force. (2009). National strategy for small and medium enterprise sector development.

52. Yee, K. T. (2011). The Influence of networking on the internationalization of SMEs: Evidence from internationalized Chinese firms. International Small Business Journal, 29(4), 374-399. Crossref

53. Zhao, X. Y., Frese, M. and Giardini, A. (2005). Business owners network size and business growth in China: The role of comprehensive social competency. In Babson- Kauffman Entrepreneurship Research Conference (BKERC), Babson College, MA, U.S.A. 